\begin{tabular}{cc}
$\begin{array}{c}\text { Yanbu Journal } \\
\text { of } \\
\text { Engineering } \\
\text { and Science }\end{array}$ & Vol. 13, December 2016 $(1438 \mathrm{H})$ \\
\hline \hline ISSN: $1658-5321$ & www.yjes.org.sa
\end{tabular}

\title{
PREPARATION AND CHARACTERIZATION OF MICA-REINFORCED POLYPROPYLENE COMPOSITES
}

\author{
Mohammed N. Alghamdi \\ Mechanical Engineering Technology Department, Yanbu Industrial College, Kingdom of Saudi Arabia \\ E-mail: alghamdim@rcyci.edu.sa
}

\begin{abstract}
This paper reports the preparation of mica-reinforced polypropylene composites by twinscrew extrusion and characterization of various properties. The composites were prepared by the varying weight percentages of the filler up to $40 \%$. Structural identification was carried out by Fourier Transform Infra-red spectroscopy and shifting of few functional groups was noted. Mechanical properties such as stress-strain measurements and impact properties showed minimal interaction between the filler and matrix owing to the difference in morphology of the components. Differential Scanning Calorimetry results showed nucleation by the filler in the composites.
\end{abstract}

Keywords: Composites; polypropylene; mica; mechanical properties.

\section{INTRODUCTION}

Nowadays, plastics have a profound effect on our daily lives, and thermoplastics are one such important plastic. In the recent decades, polypropylene (PP), particularly the aspect of filled systems, has gained much attention due to its wide range of applications. It is one of the widely used commodity plastics in electric, packaging, and automotive applications. Its excellent process ability allows the incorporation of a wide range of fillers (natural or synthetic) to suit different applications. It also has qualities such as good processing, heat distortion temperature above $100{ }^{\circ} \mathrm{C}$, recyclability and favorable price/volume/performance ratio. The use of fillers is increasingly important due to the soaring material and compounding cost and more importantly, the more stringent technical and aesthetic requirements. Inherent properties (of fillers) are crucial, particularly when selecting suitable fillers for polymer reinforcement. Incorrect choice of fillers can have a detrimental effect on the properties of the polymer. The effect of particulate fillers has been studied rigorously [1-7]. The present paper examined the effect of mica on PP with respect to varying filler loading. Mica is a natural resource found in many countries like India, Saudi Arabia, etc., and it usually develops in a book-like form. It is usually tough and flexible and can be delaminated into extremely thin, high-aspect ratio particles, which could improve the properties of plastics. Mica can be incorporated in resin systems by dry blending mica with powdered resins. It can also be added as a masterbatch concentrate. The resulting composites may be fabricated by standard thermoplastics processing methods, e.g., injection molding, blow molding, thermoforming, extrusion, rotomolding, etc. The prepared composites can be used in automotive products and plastic casings requiring outstanding stiffness and/or sound and vibration dampening. The current study concentrates on the mechanical 
and structural aspects of PP with respect to different loadings of mica, the filler.

\section{EXPERIMENTAL}

\subsection{MATERIALS AND METHODS}

Polypropylene pellets, which are commercially available from NATPET (RMLT40), and mica powder, made available by the Saudi Geological Survey, were dry-mixed in the desired compositions. Four compositions with mica content of 10, 20, 30 and 40 wt (\%) were prepared using modular co-rotating 24 $\mathrm{mm}$ twin screw extruder with an $\mathrm{L} / \mathrm{D}$ ratio of 25:1 (Haake Rheodrive 16 OS-16kW). The temperature profile was (140-160-180-200200-210-220-220-230-230 ${ }^{\circ} \mathrm{C}$ ), and the screw speed was $200 \mathrm{rpm}$. The obtained strands were pelletized and injection molded using a minijet II (Thermo) at $230{ }^{\circ} \mathrm{C}$. The molds were kept at $400{ }^{\circ} \mathrm{C}$, and the air pressure was maintained at 7 bar. The samples were designated as M0, M10, M20, M30, and M40, where $M$ stands for mica and the number stands for the amount of filler incorporated into the matrix. Tensile testing was performed using an Instron (3365) universal testing machine of $10 \mathrm{kN}$ load cell. ISO methods 527 and 178 were used, respectively, for this study. Fourier transform infrared spectroscopy (FTIR) measurements were performed using Thermo iS5 FTIR with diamond attenuated total reflectance (ATR) accessory in the range of $400-4000 \mathrm{~cm}^{-1}$. The melting and crystallization behaviors of the composites were studied on Shimadzu DSC 60 machine under nitrogen atmosphere. $5 \mathrm{mg}$ of the samples were kept in aluminum pans, and the heating rate was $100{ }^{\circ} \mathrm{C}$. The temperature profile for the measurements is as follows: heating up to $230{ }^{\circ} \mathrm{C}$ for 2 minutes, followed by cooling to room temperature $\left(27^{\circ} \mathrm{C}\right.$ ) for 2 minutes and then reheating to $230^{\circ} \mathrm{C}$. The first cooling and second heating data were utilized to plot the curves and analysis.

\section{RESULTS AND DISCUSSION}

\subsection{FTIR RESULTS}

Figure 1 shows the FTIR curves for virgin PP and the mica-reinforced composites obtained from the ATR measurements. The characteristic peaks of PP are shown at 2949, 2865, 1652, 1455, 1375, 1167, 1016, 972, 840 and $808 \mathrm{~cm}^{-1}$, respectively. On incorporation of mica, the peaks such as 2865 , 1652, 1455, $1375 \mathrm{~cm}^{-1}$ were shifted marginally. Moreover, a few peaks of 2837 , 1596, 1358, 997 and $898 \mathrm{~cm}^{-1}$ were seen in the composites showing mica incorporation. The intensity of the peaks changed with the increase in loading. However, the interaction between the polymer matrix and the filler is minimal as there is no appreciable change in the characteristic peaks for PP and mica in the composites.

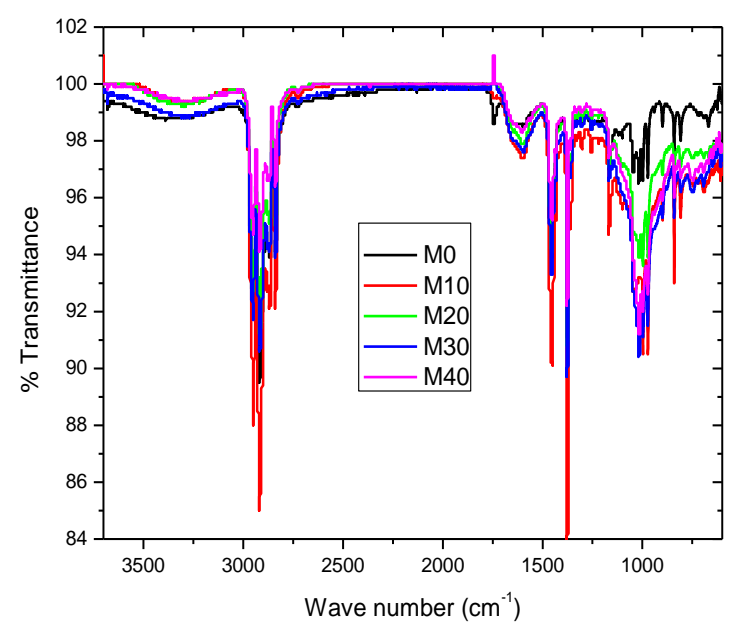

Fig. 1. FTIR curves of $\mathrm{PP}$ and $\mathrm{PP} /$ mica composites.

\subsection{MECHANICAL PROPERTIES}

Mechanical properties of the composites are very important to assess the suitability of applications for the prepared composites. In this regard, stress-strain measurements and impact testing were carried out for the composites. 


\subsection{STRESS-STRAIN MEASUREMENTS}

Figure 2 shows the behavior of Young's modulus and tensile stress with respect to filler loading. Tensile stress shows a decrease with the increase of the weight percent of mica. In this static test, due to the weak interaction between mica fillers and PP materials, the matrix is dominating, and therefore, the mica did not reinforce the system. The modulus increased with the increase in the mica weight percentage. This is because the system becomes more elastic due to the absence of interaction between mica and PP matrix materials.

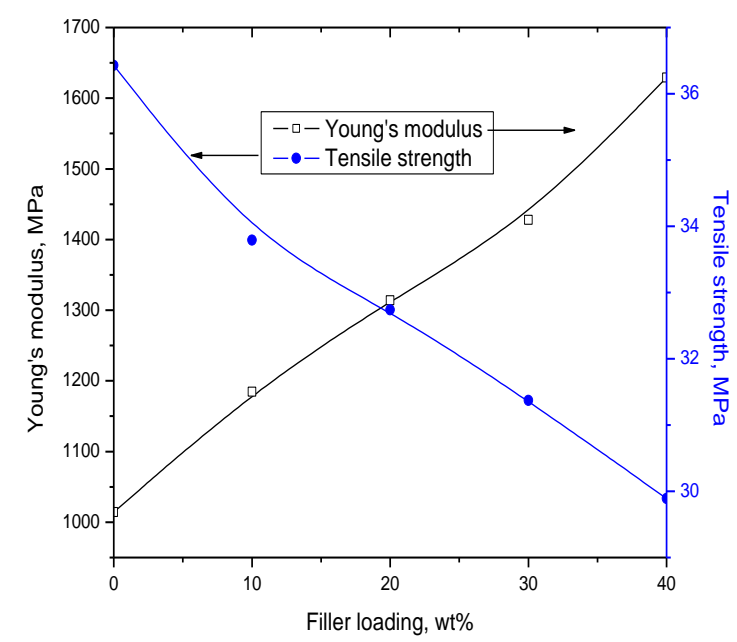

Fig. 2. Young's modulus and tensile strength of $\mathrm{PP}$ and $\mathrm{PP} / \mathrm{mica}$ composites.

\subsection{TheOretical MODELING OF YOUNG'S MODULUS}

Young's modulus can be modeled by using different mathematical equations. There are a number of parameters that affect the mechanical properties of particulate filled polymer composites, especially filler orientation, filler/matrix adhesion, and filler shape. Many equations were developed to predict the properties based on filler volume percentage [8-10]. The theories that proposed to model Young's modulus can be classified based on the nature of the matrix and reinforcements.
The matrix can be non-rigid or rigid ones. The commonly used equations are those developed by Einstein, Guth, Mooney, Kerner and Nielson [11-15].

\subsubsection{Einstein equation}

These equations are mainly used for the theoretical calculations of the properties of particulate (spherical) reinforced polymer composites. According to the Einstein equation:

$$
M_{c}=M_{m}\left(1+1.25 V_{p}\right)
$$

where $M_{c}$ and $M_{m}$ are the Young's modulus of composite and matrix, respectively, and $V_{p}$ is the particle volume fraction. Einstein's equation is applicable only for materials filled with low concentrations of non-interactive spheres. Einstein's equation implies that the stiffening or reinforcing actions of filler is independent of the size of the filler particles. This equation shows that the volume occupied by the filler is independent of the size of the filler particles and can be considered as an important variable in determining Young's modulus of the composite. The equation also assumes that the filler is more rigid than the matrix.

\subsubsection{Guth equation}

$$
M_{c}=M_{m}\left(1+1.25 V_{p}+14.1 V_{p}^{2}\right)
$$

Guth's equation is an expansion of Einstein's equation, accounting for the inter-particle interactions at higher filler concentrations.

\subsubsection{Kerner equation}

Young's modulus of spherically shaped particulate-filled polymer composites is given by Kerner's equation:

$$
M_{c}=M_{m}\left[1+\frac{V_{p} 15\left(1-\sigma_{m}\right)}{V_{m}\left(8-10 \sigma_{m}\right)}\right]
$$

where $V_{m}$ is the matrix volume fraction and $\sigma_{\mathrm{m}}$ is the Poisson's ratio of the matrix. 


\subsubsection{Quemeda equation}

$$
M_{c}=M_{m} \frac{1}{\left(1-0.5 K V_{p}\right)^{2}}
$$

where $\mathrm{K}$ is a constant normally 2.5. This variable coefficient is introduced to account or the inter-particle interactions and differences in particle geometry.

\subsubsection{Thomas equation}

$$
M_{c}=M_{m}\left(1+2.5 V_{p}+10.05 V_{p}^{2}+0.00273 e^{16.6 V_{p}}\right)
$$

Thomas equation is an empirical relationship based on the data generated with dispersed spherical particles. The experimental results were compared with theoretical predictions, and the plots are given in Figure 3. All these predictions assume that matrix and filler have no appreciable degree of interaction. The experimental results at lower filler loading matches with Guth equation, and at higher loading, the results follow Quemeda equation. Both the models were predicted taking into account the inter-particle interaction. The tensile modulus for higher loading of fillers deviates from the Guth model and is more similar to Quemeda equation, which also considered particle geometry. Owing to the layered structure of mica, the chances of interparticle interaction is more at higher loadings, which contributed to the decrease in modulus in that region.

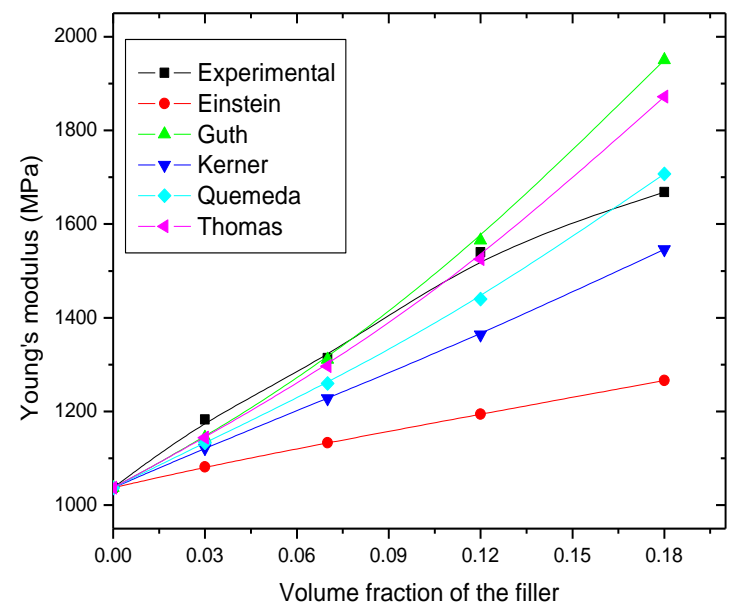

Fig. 3. Theoretical modeling of Young's modulus.

\subsection{IMPACT TESTS}

Impact tests were conducted as per ASTM/ISO standards. For each sample, 5 specimens were used, and the average is given in the tables as numerical results. Both unnotched and notched samples were tested. The obtained results are given in Tables 1 and 2 , respectively. Figure 4 shows the behavior of impact strength for untreated mica fillers in PP composite system. As the mica weight increases, the impact strength decreases. This behavior is expected because the PP is incompatible with mica as the phase is nonpolar, hydrophobic, and has low surface energy for PP while polar, hydrophilic and high surface energy is required for mica. As a composite system under impact strike, the mica/PP interface is weak and thus, creates stress concentration points or voids. Therefore, the load is not being transmitted from PP to mica for reinforcing the system. It is clear that the impact strength decreases with filler addition. This is mainly due to the reduction in elasticity $[16,17]$ of material due to filler addition, thereby, reducing the deformability of matrix and ductility, such that the composite tends to form a weak structure. An increase in the concentration of filler reduces the ability of the matrix to absorb energy, thereby, reducing the toughness and impact strength.

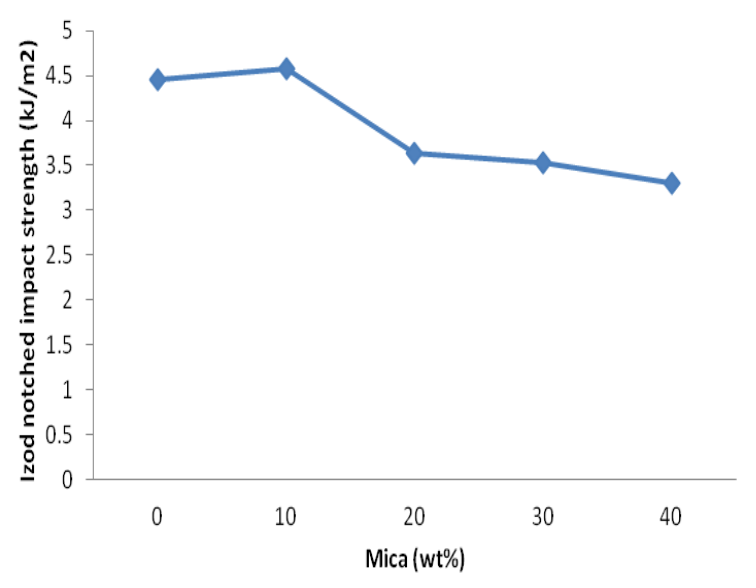

Fig. 4. Izod impact strength of PP and PP/mica composites. 


\subsection{THERMAL PROPERTIES}

Figures 5 and Figure 6 show the heating and cooling curves from DSC study. The heating curves show similar patterns for virgin $\mathrm{PP}$ and the composites. It can be seen from the curves that the melting point of the composites increases upon filler loading except for 10 $\mathrm{wt} \%$. The virgin $\mathrm{PP}$ has a melting point of $162{ }^{\circ} \mathrm{C}$ and the $10 \mathrm{wt} \%$ loading of mica slightly lowers it to $160{ }^{\circ} \mathrm{C}$. However, the melting point shows an increase of up to $3{ }^{\circ} \mathrm{C}$ for the remaining composites.

TABLE 1: UNNOTCHED SAMPLES; WIDTH: $10 \mathrm{MM}$ AND THICKNESS: $4 \mathrm{MM}$; IMPACT VELOCITY: $3.03 \mathrm{M} / \mathrm{S}$.

\begin{tabular}{|c|c|c|c|}
\hline Sample & Energy $(\mathbf{J})$ & $\begin{array}{c}\text { Resilience } \\
(\mathbf{J} / \mathbf{m})\end{array}$ & $\begin{array}{c}\text { Absorption } \\
\text { energy }(\%)\end{array}$ \\
\hline $\mathrm{PP}$ & $3.992 \pm 0.526$ & $997.2 \pm 43.1$ & $79.74 \pm 8.2$ \\
\hline $\begin{array}{c}\mathrm{PP}+10 \% \\
\text { mica }\end{array}$ & $2.497 \pm 0.408$ & $624.5 \pm 49.6$ & $49.88 \pm 8.7$ \\
\hline $\begin{array}{c}\text { PP }+20 \% \\
\text { mica }\end{array}$ & $1.992 \pm 0.412$ & $497.6 \pm 41.4$ & $39.78 \pm 7.3$ \\
\hline $\begin{array}{c}\text { PP }+30 \% \\
\text { mica }\end{array}$ & $1.286 \pm 0.347$ & $321.7 \pm 39.6$ & $25.695 \pm 5.9$ \\
\hline $\begin{array}{c}\text { PP }+40 \% \\
\text { mica }\end{array}$ & $0.936 \pm 0.272$ & $237.6 \pm 38.4$ & $18.72 \pm 4.3$ \\
\hline \multicolumn{2}{|c|}{} & & \\
\hline
\end{tabular}

TABLE 2: NOTCHED SAMPLES; WIDTH: 8 MM AND THICKNESS: $4 \mathrm{MM}$; IMPACT VELOCITY: $3.03 \mathrm{M} / \mathrm{S}$.

\begin{tabular}{|c|c|c|c|}
\hline Sample & Energy (J) & $\begin{array}{c}\text { Resilience } \\
(\mathbf{J} / \mathbf{m})\end{array}$ & $\begin{array}{c}\text { Absorption } \\
\text { energy (\%) }\end{array}$ \\
\hline $\mathrm{PP}$ & $0.1425 \pm 0.012$ & $35.55 \pm 4.7$ & $2.84 \pm 0.31$ \\
\hline $\begin{array}{c}\mathrm{PP}+10 \% \\
\text { mica }\end{array}$ & $0.1465 \pm 0.019$ & $36.56 \pm 6.5$ & $2.93 \pm 0.29$ \\
\hline $\begin{array}{c}\mathrm{PP}+20 \% \\
\text { mica }\end{array}$ & $0.1165 \pm 0.015$ & $29.09 \pm 5.3$ & $2.33 \pm 0.38$ \\
\hline $\begin{array}{c}\mathrm{PP}+30 \% \\
\text { mica }\end{array}$ & $0.1132 \pm 0.015$ & $28.23 \pm 5.7$ & $2.26 \pm 0.37$ \\
\hline $\begin{array}{c}\text { PP }+40 \% \\
\text { mica }\end{array}$ & $0.1055 \pm 0.010$ & $26.34 \pm 3.8$ & $2.105 \pm 0.31$ \\
\hline
\end{tabular}

In short, the melting point of the composites did not improve much on the addition of the present filler. From Figure 6, the crystallization behavior of the composites can be analyzed on the addition of mica filler to PP.

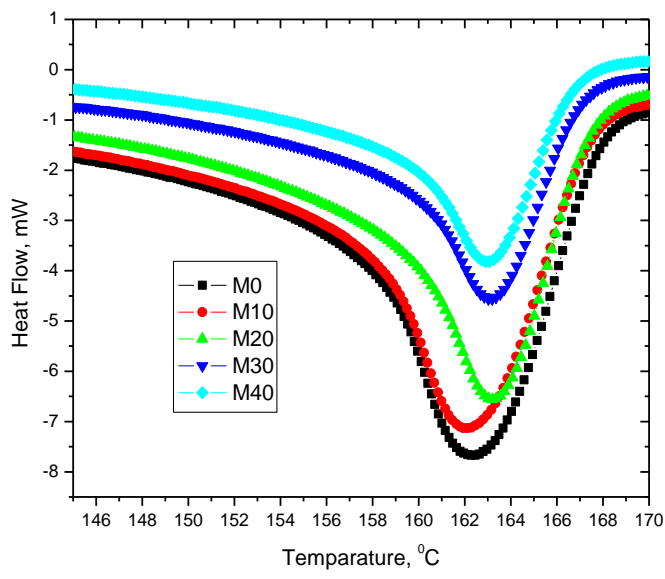

Fig. 5. DSC heating curves of $\mathrm{PP}$ and $\mathrm{PP} / \mathrm{mica}$ composites.

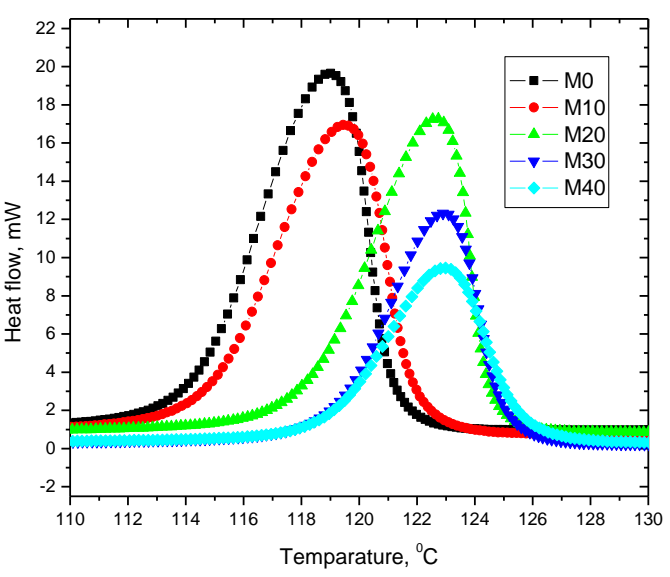

Fig. 6. DSC cooling curves of PP and $\mathrm{PP} / \mathrm{mica}$ composites.

The crystallization temperature for $\mathrm{PP}$ is $118{ }^{\circ} \mathrm{C}$. The composites show a gradual increase in crystallization temperature, and the increment is worth approximately $6{ }^{\circ} \mathrm{C}$ for $40 \mathrm{wt} \%$ composites. This increase in crystallization temperature can be attributed to the nucleation effect of the added filler in the system.

\section{CONCLUSIONS}

Based on the structural analysis and thermomechanical analysis of the mica incorporated PP composites, it can be concluded that the 
extrusion followed by injection molding is a good method for preparing polymeric composites. Here, the material used are from natural resources of Saudi Arabia and its potential is not yet fully exploited. The thermo-mechanical properties did not show drastic improvements, even though mica is believed to have higher inherent properties such as high elastic modulus and thermal stability. This behavior is believed to be due to the lack of interaction between the polymer matrix and the filler corroborated by the IR results. Therefore, suitable modification of mica to form better bonding or interaction between the polymer and filler is recommended as a future prospect.

\section{REFERENCES}

[1] Leong, Y. W., Bakar, M. B. A., Ishak, Z. A. M., Ariffin, A., Pukanszky, B. 2004. Comparison of the Mechanical Properties and Interfacial Interactions between Talc, Kaolin, and Calcium Carbonate Filled Polypropylene Composites. J. Appl. Polym. Sci. 91: 3315-3326.

[2] Sancaktar, E., Walker, E. 2004. Effects of Calcium Carbonate, Talc, Mica, and Glass-Fiber Fillers on the Ultrasonic Weld Strength of Polypropylene. J. Appl. Polym. Sci. 94: 19861998.

[3] Ahmad, F. N., Mariatti, J., Samayamutthirian, P., Azizi, M. A. K. 2008. Effect of Particle Shape of Silica Mineral on the Properties of Epoxy Composites. Compos. Sci. Technol.68:346-353.

[4] Wypych, G. 2000. Handbook of Fillers. 2nd ed., New York: Chem Tec.

Roberts, D. H. 1999. Chemical Coupling of Polypropylene Systems Containing Non-Glass Fillers. J. Vinyl Addit. Technol. 5:231-234.

[5] Shenoy, A. V. 1999. Rheology of Filled Polymer Systems. 1st ed., Dordrecht: Kluwer Academic Publishers.
[6] Karger-Kocsis, J. 1994. Polypropylene Structure, Blends and Composites. 1st ed., Berlin: Springer.

[7] Rösch, J. 1995. Modeling the mechanical properties in polypropylene/polyamide-6 blends with core shell morphology. Polym. Eng. Sci. 35: 1917-1922.

[8] Bliznakov, E. D., White, C. C., Shaw, M. T. 2000. Mechanical Properties of Blends of HDPE and Recycled Urea-Formaldehyde Resin. J. Appl. Polym. Sci. 77: 3220-3227.

[9] Guth, J. 1945. Theory of Filler Reinforcement. J. Appl. Phys. 12: 20-25.

[10] Fukahori, Y., Hon, A. A., Jha, V., Busfield, J. J. C. 2013. Modified Guth-Gold Equation for Carbon Black-Filled Rubbers. Rub. Chem. Technol.86: 218-232.

[11] Liu, Z., Gilbert, J. 1996. Structure and properties of talc-filled polypropylene: Effect of phosphate coating. J. Appl. Polym. Sci. 59:1087-1098.

[12] Margolina, A., Wu, S. 1988. Percolation model for brittle-tough transition in nylon/rubber blends. Polymer. 29: 2170-2173.

[13] Yang, C.Q., Mouldev, J.F., Iateley, W. 1988. XPS studies of the bonding and hydrolysis of di(dioctyl)pyrophosphate ethylene titanate coupling agent on metal surfaces. J. Adhes. Technol. 2: 11-19.

[14] Thomas, S. P., Joseph, K., Thomas, S. 2004. Mechanical properties of titanium dioxide-filled polystyrene microcomposites. Mater. Lett. 58: 281- 289 .

[15] Bose, S., Mahanwar, P.A. 2004. Effect of Particle Size of Filler on Properties of Nylon-6. J. Miner. Mater. Charact. Eng. 3: 23-31.

[16] Sreekanth, M.S., Joseph, S., Mhaske, S.T., Mahanwar, P.A., Bambole, V.A. 2011. Effects of Mica and Fly Ash Concentration on the Properties of Polyester Thermoplastic Elastomer Composites. J. Thermoplast. Compos. Mater. 24: 317-323. 


\section{تحضير وتوصيف خواص خليط مادة البولييروبلين المقوى بالمايكا}

$$
\text { محمد ناصر الغامدي }
$$

قسم تكنولوجيا الهنسة الميكانيكة، كلية ينبع الصناعية، المملكة العربية السعودية

الملخص:

نعرض في هذا البحث تحضير مادة المايكا المقوية والتي تم خلطها مع مادة البولي بروبيلين البلاستيكي ليتم تحضير نظام مركب بإستخدام محرك البثق البلاستيكي ثنائي الدفع وبذلك يتم التعرف وتوصيف الخواص المتعلقة بهذا النظام. تم تحضير المركب عن طريق تغيير نسبة وزن المادة المقوية في النظام لتصل الى ـ ـ٪. تم التعرف على تركيبة البناء لهذا المركب من خلال جهاز متحول فورييه والذي بين تحول بعض المجموعات الوظيفية للمركب. بينت الدراسة الخواص الميكانيكية كالاجهاد المتعلق بالاسنطاله و التأثير القليل من الاستجابه، و المتوقعة نظر اً لاختلاف تركيبة كل مادة. كما بين جهاز التفاضل الضوئي الكالوري بعض التتوي للمادة المقوية 